\title{
Determination and Characterization of Thermostable Esterolytic Activity from a Novel Thermophilic Bacterium Anoxybacillus gonensis A4
}

\author{
Özlem Faiz ${ }^{1}$, Ahmet Colak ${ }^{1, *}$, Nagihan Saglam, Sabriye Çanakçi ${ }^{2}$ and Ali Osman Beldüz ${ }^{2}$ \\ Departments of ${ }^{1}$ Chemistry and ${ }^{2}$ Biology, Karadeniz Technical University, 61080 Trabzon, Turkey
}

Received 22 January 2007, Accepted 16 March 2007

\begin{abstract}
A novel hot spring thermophile, Anoxybacillus gonensis A4 (A. gonensis A4) was investigated in terms of capability of tributyrin degradation and characterization of its thermostable esterase activity by the hydrolysis of $p$ nitrophenyl butyrate (PNPB). It was observed that $A$. gonensis A4 has an esterase with a molecular weight of 62 kDa. The extracellular crude preparation was characterized in terms of substrate specificity, $\mathrm{pH}$ and temperature optima and stability, kinetic parameters and inhibition/ activation behaviour towards some chemicals and metal ions. Tributyrin agar assay showed that A. gonensis A4 secreted an esterase and $V_{\max }$ and $K_{\mathrm{m}}$ values of its activity were found to be $800 \mathrm{U} / \mathrm{L}$ and $176.5 \mu \mathrm{M}$, respectively in the presence of PNPB substrate. The optimum temperature and $\mathrm{pH}$, for $A$. gonensis $\mathrm{A} 4$ esterase was $60-80^{\circ} \mathrm{C}$ and 5.5 , respectively. Although the enzyme activity was not significantly changed by incubating crude extract solution at $30-70^{\circ} \mathrm{C}$ for $1 \mathrm{~h}$, the enzyme activity was fully lost at $8^{\circ} \mathrm{C}$ for same incubation period. The $\mathrm{pH}$-stability profile showed that original crude esterase activity increased nearly 2-fold at pH 6.0. The effect of some chemicals on crude esterase activity indicated that $A$. gonensis A4 produce an esterase having serine residue in active site and -SH groups were essential for its activity.
\end{abstract}

Keywords: Anoxybacillus, Esterase, Lipase, Thermophile, Thermostability

\section{Introduction}

Esterases catalysing the cleavage and formation of ester bonds are known as $\alpha / \beta$-hydrolases (EC 3.1.1.X) (Ollis et al., 1992). They are widely distributed in animals, plants and microorganisms

\footnotetext{
* To whom correspondence should be addressed.

Tel: 90-462-3772489; Fax: 90-462-3773661

E-mail: acolak@ktu.edu.tr
}

(Bornscheuer, 2002). Among esterases true esterases (EC 3.1.1.1, carboxyl ester hydrolases) hydrolyze esters of short chain carboxylic acids $(\leq 12)$ and lipases (EC 3.1.1.3, triacylglycerol hydrolases) display maximum activity towards insoluble long chain $(C \geq 12)$ acylglycerides (Eggert et al., 2002).

Microbial esterases and lipases are of considerable interest because of their potential application in biotechnology. The major reason of limiting industrial usage of known esterases is their limited thermostability, mainly at high temperatures, and $\mathrm{pH}$ stability in operating industrial conditions. Therefore the search for new microbial enzyme sources is important for the development of new thermostable enzymes and applications. The correlation between thermostability of an enzyme in water and its resistance to denaturation in organic solvent has been reported earlier (Owusu and Cowan, 1989). For this reason thermostable enzymes are attractive not only to be used in aqueous media but also in organic media (Kademi et al., 1999). Thermostable enzymes are usually screened from thermophilic or hyperthermophilic organisms (Gowland et al., 1987).

In organic media, lipases and esterases catalyse esterification, interesterification, alcoholysis or acidolysis reactions (Kawamoto et al., 1987). The synthesis of flavor esters for food industry, modification of triglycerides for fat and oil industry, resolution of racemic mixtures used for the synthesis of fine chemicals for the pharmaceutical industry can be performed (Molinari et al., 1996). The carboxylesterase originated from Bacillus subtilis has been used in the synthesis of naproxen as a nonsteroidal anti-inflammatory drug (Quax and Broekhuizen, 1994) and 2-arylpropionic acids with high enantioselectivity (Azzolina et al., 1995). Efficent kinetic resolutions were achieved in the synthesis of primary alcohols by esterase from Bacillus coagulans (Baumann et al., 2000) and secondary alcohols from Bacillus stearothermophilus (Molinari et al., 1996). The cloning, expression, purification and biochemical characterization of esterolytic enzymes from Bacillus species were reported (Kademi et al., 2000a; Markossian et al., 2000; Eggert et al., 2002). Recently, diphenolases from Anoxybacillus kestanbolensis strains $\mathrm{K} 1$ and $\mathrm{K} 4^{\mathrm{T}}$ were studied (Yildirim et al., 2005). 
Recently, a novel hot spring thermophile, Anoxybacillus gonensis A4, was isolated and characterized based on its biochemical, taxonomic and genetic properties (Belduz et al., 2003). The present study was aimed at evaluating the ability of this thermophilic strain for degradation of $p$-nitrophenyl esters and characterization of its extracellular thermostable esterase activity. Many researches on screening and characterization of industrial extracellular and intracellular enzyme extract such as lipase, catecholase etc. from different organisms were reported (Lopes et al., 2002; Yildirim et al., 2005). Over the past few years, immobilization of enzymes and especially the whole cell immobilization has caused an increase in the usage of enzymes in industrial process. Whole cell immobilization not only eliminates expensive operations of enzyme purification steps, but also keeps the enzyme in its natural environment and causes the greater resistance to environmental changes and higher operational stability (Kierstan and Coughlan 1985). The data obtained from this study will light the way for the further investigation of immobilization of A. gonensis A4 for thermostable crude esterase activity.

\section{Materials and Methods}

Materials. Substrates were purchased from Sigma Chemical Co. (St. Louis) and other reagents were of analytical grade and used as obtained.

Screening of esterolytic enzyme producing thermophile. A novel thermophile Anoxybacillus gonensis A4 (A. gonensis A4) was screened for its esterolytic activity on tributyrin agar plate containing $1.5 \%$ tributyrin in Luria-Bertani (LB) solid medium at $60^{\circ} \mathrm{C}$ for three days. Further 4 days incubation at $4^{\circ} \mathrm{C}$ was done to bright clear zone on the plate (Suoniemi and Tynkkynen 2002).

Culture media and growth conditions. The original Luria-Bertani (LB) liquid medium contained $(\mathrm{g} / \mathrm{L}$ in distilled water) yeast extract 5.0, bactotryptone 10.0 and $\mathrm{NaCl} 5.0$ at $\mathrm{pH}$ 7.5. LB medium was used to observe both activity and growth profiles of $A$. gonensis A4 at $60^{\circ} \mathrm{C}$ up to $24 \mathrm{~h}$ on a shaker operating at $200 \mathrm{rpm}$. LB medium supplemented with $0.3 \%$ carboxymethyl cellulose as an emulsifier and secondary carbon source was used only for activity profiles of the isolates at the same conditions. These profiles provided optimization of culture medium and growth conditions.

Preparation of extracellular crude extract. The extracellular enzyme extract was prepared by centrifugation of cells, grown in supplemented liquid medium for $15 \mathrm{~h}$, at $4,000 \mathrm{rpm}$ for $20 \mathrm{~min}$. The pellet was discarded and the supernatant was used as crude extracellular enzyme extract for characterization and determination of the esterolytic activity (Nawani and Kaur, 2000).

Protein determination. Lowry method with bovine serine albumin as standard was used to determine the protein quantity of the enzyme extract. Graphic interpolation on a calibration curve at 650 nm was used to obtain values (Lowry et al., 1951).
Electrophoresis. Electrophoresis was performed in 12\% SDSPAGE for extracellular crude extracts according to MusidlowskaPersson and Bornscheuer (Musidlowska-Persson and Bornscheuer, 2003) on a Hoeffer SE 600 Series Electrophoresis dual slab cell unit. Then, the gel was incubated in a solution containing $0.5 \%$ Triton X-100 in Tris buffer $(0.1 \mathrm{M}$, adjusted to $\mathrm{pH} 7.5$ with $\mathrm{HCl})$ for $1 \mathrm{~h}$ renaturation. Renaturated gel was incubated for $30 \mathrm{~min}$ in a $1: 1$ mixture of solution A ( $8 \mathrm{mg} \alpha$-naphtyl acetate dissolved in $3 \mathrm{~mL}$ acetone and added to $0.1 \mathrm{M}$ Tris buffer which $\mathrm{pH}$ is 7.5$)$ and $\mathrm{B}$ (20 mg Fast Red dissolved in 0.1 M Tris buffer which $\mathrm{pH}$ is 7.5) for activity staining.

Determination of esterolytic activity. Esterolytic activity was determined by using the spectrophotometric assay described by Lee et al., (1999). For the preparation of stock substrate solution, $p$ nitrophenyl butyrate (PNPB) was dissolved in acetonitrile at a concentration of $10 \mathrm{mM}$. The substrate solution included stock substrate solution, ethanol and $50 \mathrm{mM}$ phosphate buffer $(\mathrm{pH} 7.5)$ in ratio of $1: 4: 95(\mathrm{v} / \mathrm{v} / \mathrm{v})$, respectively. To prepare the reaction mixture, $0.3 \mathrm{~mL}$ of the cell free supernatant was added to $0.9 \mathrm{~mL}$ of the substrate solution. After the incubation of the reaction mixture at $60^{\circ} \mathrm{C}$ for $15 \mathrm{~min}$, the change in absorbance at $405 \mathrm{~nm}$ was monitored. The amount of released $p$-nitrophenol ( $p$-NP) was determined for the esterolytic activity. The non enzymatic hydrolysis was substracted by using a blank without enzyme. During this study, optima values obtained were adapted to standard enzymatic assays. One unit of enzyme activity was defined as $1 \mu \mathrm{mol}$ of $p$-NP formed per min under assay conditions.

Substrate specificity. The substrate specificity of crude enzyme extract was determined at standard reaction conditions by using PNPB in acetonitrile and $p$-nitrophenyl laurate (PNPL) in DMSO at $10 \mathrm{mM}$ concentration of stock solution.

Optimum pH and pH stability. The effect of $\mathrm{pH}$ on the esterase activity was measured at $60^{\circ} \mathrm{C}$ by using $50 \mathrm{mM}$ of following buffers; sodium acetate $(\mathrm{pH} 4.0-5.5)$ and potassium phosphate $(\mathrm{pH}$ 6.0-8.0) (Lee et al., 1999). The same buffers with $1.0 \mathrm{pH}$ value increments, and $\mathrm{NaOH}-$ Glycine buffer at $\mathrm{pH} 9.0$ were used to determine the $\mathrm{pH}$ stability of the enzyme extract. The mixture of enzyme extract and the buffers given above $(1: 1)$ was incubated for $24 \mathrm{~h}$ at $4^{\circ} \mathrm{C}$ and then the residual activity was assayed by using $0.3 \mathrm{~mL}$ of this mixture at optimum conditions with PNPB as substrate (Yildirim et al., 2005, Zhang et al., 2005). The percentage residual esterase activity was calculated by comparison with unincubated enzyme.

Optimum temperature and thermostability. The temperature optimum assay was performed for different temperatures in the range of $30-90^{\circ} \mathrm{C}$ at the optimum $\mathrm{pH}$ value using a circulation water bath. The reaction mixtures were incubated for $15 \mathrm{~min}$ at various temperatures indicated above. Then, the relative activity was determined spectrophotometrically at $405 \mathrm{~nm}$ as rapidly as possible. In order to determine the thermal stability of the enzyme, the crude enzyme extract in test tubes were incubated at temperatures of 30$80^{\circ} \mathrm{C}$ with $10^{\circ} \mathrm{C}$ increments for $1 \mathrm{~h}$, rapidly cooled and brought to $25^{\circ} \mathrm{C}$. After the mixture reached to room temperature, the enzyme activity was assayed under the standard reaction conditions at optimum pH value (Özen et al., 2004; Yildirim et al., 2005). 
Effect of substrate concentration on esterolytic activity. A substrate saturation curve was obtained by plotting the final substrate concentration in the range of $0-900 \mu \mathrm{M}$ versus esterase activity in the presence of PNPB as substrate. The MichaelisMenten constant $\left(K_{m}\right)$ and the maximum velocity of the reaction $\left(V_{\text {max }}\right)$ were calculated from Lineweaver-Burk plot (Lineweaver and Burk, 1934)

Effect of protein concentration on esterolytic activity. The hydrolysis of PNPB by crude enzyme extract was performed for different protein concentration ranging from 0.012 to $1.215 \mathrm{mg} / \mathrm{mL}$. The activity was assayed under standard reaction condition at the optimum $\mathrm{pH}$.

Effect of metal ions on esterolytic activity. The effect of various metal ions on the enzyme activity was tested by addition of $1 \mathrm{mM}$ chloride salts $\mathrm{Na}^{+}$and $\mathrm{K}^{+}$for monovalent, $\mathrm{Cu}^{2+}, \mathrm{Ni}^{2+}, \mathrm{Ca}^{2+}, \mathrm{Mn}^{2+}$, $\mathrm{Hg}^{2+}, \mathrm{Zn}^{2+}, \mathrm{Co}^{2+}, \mathrm{Cd}^{2+}$ for divalent and $\mathrm{Cr}^{3+}$ for trivalent ions. After addition of each metal ion solution on enzyme extract $(1: 1)$ and incubation of this mixture for $20 \mathrm{~min}$ at room temperature, the activity was assayed using $0.3 \mathrm{~mL}$ aliquot of metal ion:extract solution and PNPB as substrate. The residual activities were measured by comparison with standard assay mixture with no metal ion added and diluted enzyme extract in the ratio of $1: 1$, at optimum pH (Lee et al., 1999).

Effect of some chemicals and chelating agent on esterolytic activity. The esterase activity was monitored in the presence of 2mercaptoethanol and ethylenediamine tetraacetic acid (EDTA) at the concentration of 2, 2.5 and $5 \mathrm{mM}$, dithiothreitol (DTT) and $p$ methylphenyl sulfonylfluoride (PMSF) at the concentration of 50, $100,250 \mu \mathrm{M}$. The behaviour of the crude enzyme extract in the presence of these chemicals was assayed as indicated in the section of metal ion effect.

Statistical analysis of data. Analysis of variance of the data was performed with SPSS 10.0 for Windows (USA). The LSD multiple range test was employed to determine the statistical analysis. In all Figures and tables, data points represent mean of three determinations $(\mathrm{p} \leq 0.05)$.

\section{Results and Discussion}

Esterase secretion by Anoxybacillus gonensis A4 (A. gonensis A4) (Beldüz et al., 2003) on tributyrin agar plate was qualitatively monitored by the formation of clear zone around the colonies after three days incubation at $60^{\circ} \mathrm{C}$. A further incubation at $4^{\circ} \mathrm{C}$ for 4 days was performed in order to make the clear zone more visible (Fig. 1a). It can be easily extracted from the result of this qualitative test that $A$. gonensis A4 produce an extracellular enzyme responsible for the degradation of tributyrin. This method is not specific for esterase or lipase (Suoniemi and Tynkkynen 2002; Hotta et al., 2002) but shows that A. gonensis A4 can hydrolyze ester bounds with short chain.

SDS-PAGE gel electrophoresis on crude enzymes stained with a 1:1 mixture solution of $0.1 \mathrm{M} \alpha$-naphtyl acetate and 0.1

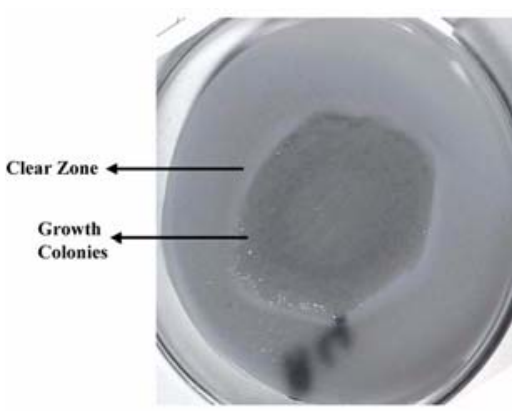

(A)
(B)

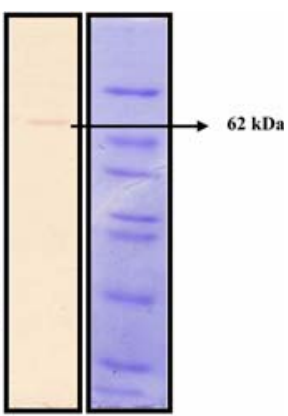

Fig. 1. (A) Esterolytic activity detection of A. gonensis A4. Determination of the extracellular esterolytic activity for $A$. gonensis $\mathrm{A} 4$ on tributyrin agar plate containing $1.5 \%$ tributyrin in Luria-Bertani (LB) solid medium. (B) SDS-PAGE for $A$. gonensis A4 crude extracellular extract. Lane 1: Esterase on renaturated gel stained with $\alpha$-naphtyl acetate and Fast Red, Lane 2: Molecular mass standard (albumin $66 \mathrm{kDa}$, ovalbumin $45 \mathrm{kDa}$, glyceraldehyde-3-phosphate dehydrogenase $36 \mathrm{kDa}$, carbonic anhydrase $29 \mathrm{kDa}$, trypsinogen $24 \mathrm{kDa}$, trypsin inhibitor $20.1 \mathrm{kDa}, \alpha$-Lactalbumin $14.2 \mathrm{kDa}$, aprotinin $6.5 \mathrm{kDa}$ ).

M Fast Red solution from A. gonensis A4 indicated the presence of an esterase having molecular weight of approximately $62 \mathrm{kDa}$ (Fig. 1b). It was reported that the molecular weights of Bacillus circulans esterase, Vibrio harveyi lipase and a carboxyl esterase from a hyperthermophilic archeon were found to be 95,61 and $34 \mathrm{kDa}$, respectively (Kademi et al., 2000a; Hotta et al., 2002; Teo et al., 2003).

It is known that composition of growth culture medium affects bacterial lipase/esterase production (Choi and Lee 2001; Lima et al., 2003). While growing, the presence of an esterase activity of this isolate was checked by the hydrolysis of $p$-nitrophenylbutyrate (PNPB) to $p$-nitrophenol. Crude enzyme extracts prepared from each $A$. gonensis A4 grown in LB medium and LB medium supplemented with $0.3 \%$ carboxymetyl cellulose reached the activity maximum value after 18 and $15 \mathrm{~h}$ incubation period, respectively, in the presence of PNPB substrate. It was observed that maximum activity was higher in the presence of carboxymetyl cellulose in culture medium (Fig. 2). The effect of surfactants on the production of Penicillium camembertii Thom PG-3 lipase was reported (Tan et al., 2004).

PNPB as a short chain nitrophenyl ester and $p$-nitrophenyl laurate (PNPL) as a long chain nitrophenyl ester were tested for substrate specificity of the crude esterase. In the presence of PNPB and PNPL, hydrolytic activities of crude extracts were measured as 347 and $48 \mathrm{U} / \mathrm{L}$, respectively, at the end of $15 \mathrm{~h}$ bacterial growth period (Fig. 2). Substrate specificity clearly shows that the crude enzyme extract utilize both of these esters but possesses esterase activity since hydrolysis of PNPB was approximately 7-fold higher. This is in good agreement with the earlier reports (Kademi et al., 1999, Teo et al., 2003). 


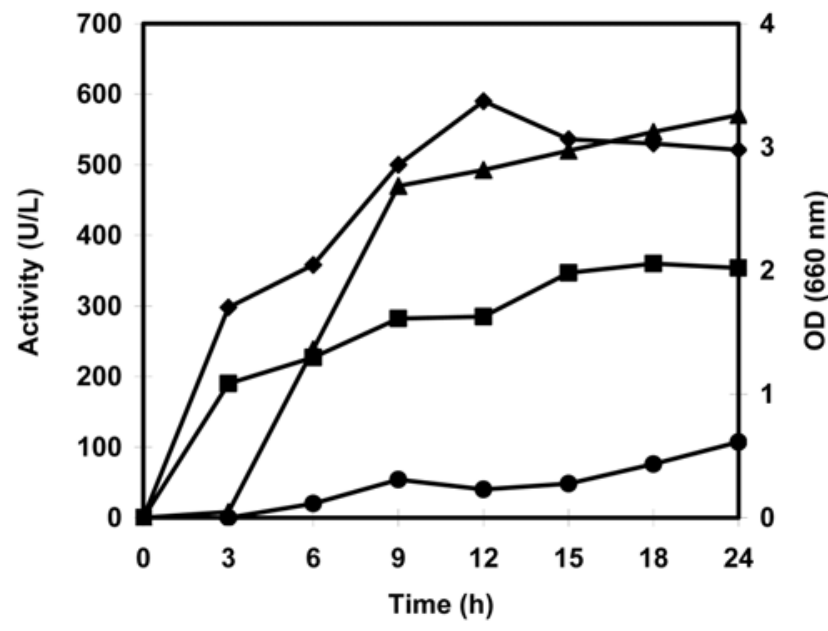

Fig. 2. Activity and growth profiles of $A$. gonensis A4. Activity profiles of $A$. gonensis A4 growth in LB medium in the presence of $p$-nitrophenyl laurate, $p$-nitrophenyl butyrate substrates and $0.3 \%$ carboxymethylcellulose supplemented LB medium in the presence of $p$-nitrophenyl butyrate substrate. Reaction mixture contained ethanol, $\mathrm{pH} 7.5$ phosphate buffer and $1 \mathrm{~mL}$ of $10 \mathrm{mM}$ of $p$-nitrophenyl butyrate in acetonitrile and $p$-nitrophenyl laurate in DMSO. Growth profile of A. gonensis A4 in LB medium.

The amount of protein $(\mathrm{w} / \mathrm{v})$ in the extracellular medium was determined to be $6.3 \mathrm{mg} / \mathrm{mL}$. The effect of protein content on the PNPB esterase activity was investigated by varying protein concentration between 0.012 to $1.215 \mathrm{mg} / \mathrm{mL}$. The enzyme activity gradually increased to $0.45 \mathrm{mg} / \mathrm{mL}$ protein content and remained constant at protein levels greater than $0.65 \mathrm{mg} / \mathrm{mL}$. Therefore, crude enzyme extracts from $A$. gonensis A4 having $0.3 \mathrm{mg} / \mathrm{mL}$ protein content was used for the kinetic studies. Similar observations were reported for the crude depolymerases (Colak and Güner 2004; Çolak et al., 2005).

The effect of $\mathrm{pH}$ on the $A$. gonensis $\mathrm{A} 4$ esterase activity was determined by using PNPB as a substrate with the $\mathrm{pH}$ buffers ranging from 4.0 to 8.0 . $\mathrm{pH}$ optimum of this enzyme was observed at 5.5 (Fig 3). In addition, crude enzyme preparation showed a second peak at $\mathrm{pH}$ 7.5. This might indicate isoforms of the esterase or different enzymes hydrolyzing PNPB in the crude enzyme preparations. Similar results were reported earlier for polyphenol oxidases (Yildirim et al., 2005; Colak et al., 2005). It is also reported that esterases have a $\mathrm{pH}$ optimum at approximately 6.0 while lipases show maximum activity around 8.0 (Fojan et al., 2000). Further investigations were carried out at $\mathrm{pH}$ 5.5. The optimum $\mathrm{pH}$ values for extracellular esterases were found different among bacteria (Jung et al., 2003).

The residual activity of the esterase from A. gonensis A4 was determined after $24 \mathrm{~h}$ of incubation at various $\mathrm{pH}$ values ranging from 4.0 to 9.0 (Fig. 3 inset). The $\mathrm{pH}$-stability profiles showed that original crude esterase activity nearly 2 -fold increased at $\mathrm{pH}$ 6.0. In addition, it appears that the esterase is

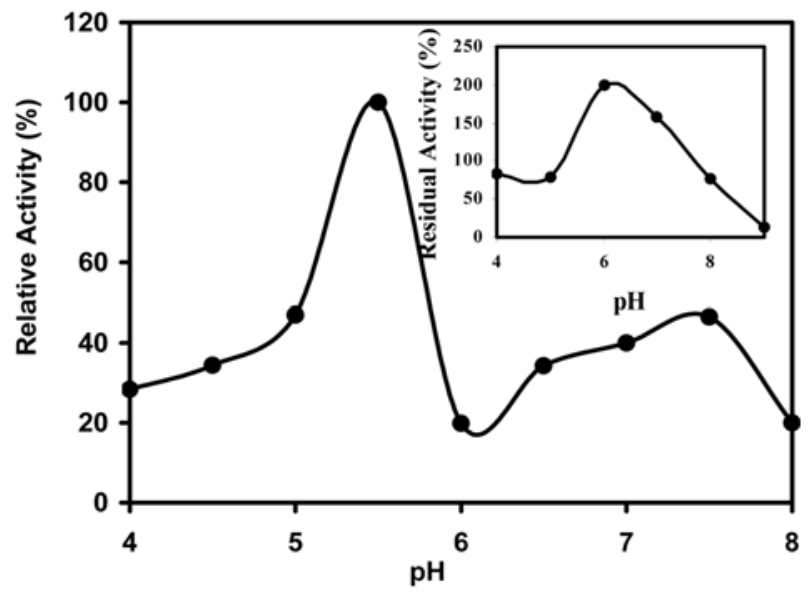

Fig. 3. Effect of $\mathrm{pH}$ on activity and $\mathrm{pH}$ stability of $A$. gonensis A4. Effect of $\mathrm{pH}$ on activity of A. gonensis $\mathrm{A} 4$ esterolytic activity in $50 \mathrm{mM}$ acetate buffer (4.0-5.5), in phosphate buffer (6.0-8.0). The reaction mixture contained $p$-nitrophenyl butyrate and ethanol in the buffer indicated above. Inset: pH stability of the extracellular esterolytic activity of A. gonensis A4 residual activity after $24 \mathrm{~h}$ incubation at desired $\mathrm{pH}$ at $4^{\circ} \mathrm{C}$. The activity was assayed under standard conditions, $\mathrm{pH} 5.5$ acetate buffer at $60^{\circ} \mathrm{C}$.

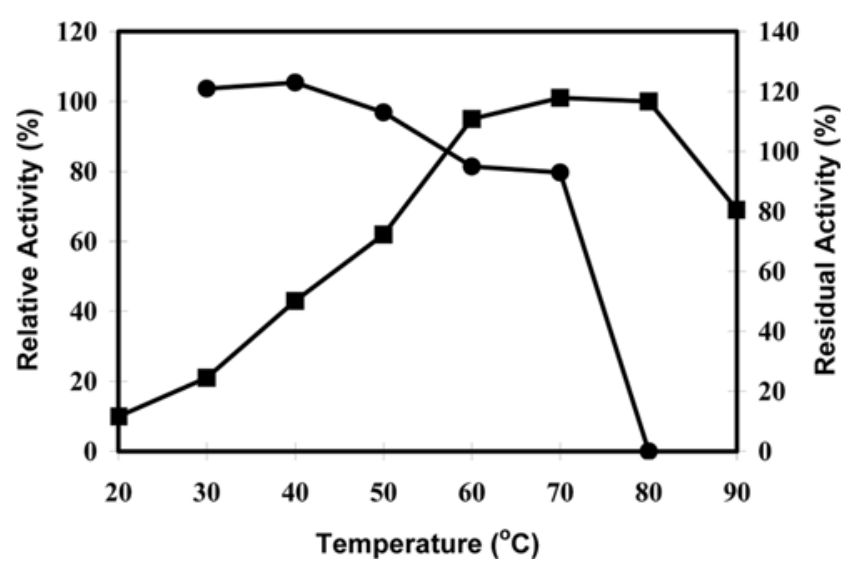

Fig. 4. Effect of temperature on activity and thermostability of $A$. gonensis A4. Temperature optimum and stability profiles of $A$. gonensis A4 esterase that hydrolase $p$-nitrophenyl butyrate. The reaction mixture in $\mathrm{pH} 5.5$ acetate buffer was incubated for different temperatures and the standard activity assay was performed at $405 \mathrm{~nm}$. For temperature stability, the crude enzyme extract was incubated at temperatures of $30-80^{\circ} \mathrm{C}$. The percentage residual activity was compared with unincubated enzyme.

quite stable at the $\mathrm{pH}$ range from 4.0 to 8.0 . The stability of the enzyme in acidic and neutral $\mathrm{pHs}$ and at high temperatures suggests its usefulness in industrial applications. The $\mathrm{pH}$ stability profile of thermophilic Bacillus sp. esterase showed that enzyme retained almost its original activity when it was incubated at $\mathrm{pH} 4.0-8.0$ up to $10 \mathrm{~h}$ at room temperature, but a decline of enzyme activity was observed at the end of $24 \mathrm{~h}$ incubation period (Burcu et al., 2006). 


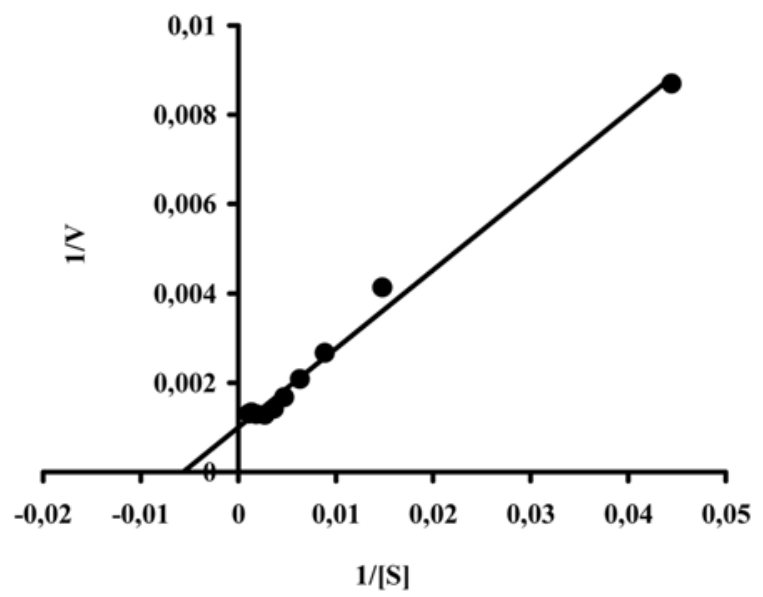

Fig. 5. Kinetic analysis of the reaction rates. Lineweaver-Burk plot of A. gonensis A4 esterase for the kinetic analysis of the reaction rates, at a series of concentrations for $p$-nitrophenyl butyrate.

Fig. 4 shows the thermal activity profile having a shoulder between $60-80^{\circ} \mathrm{C}$ for extracellular crude esterase from $A$. gonensis A4. It was observed that enzyme preparation has a higher esterase activity at higher temperatures above $50^{\circ} \mathrm{C}$ and this result was well consistent with the opinion which thermostable enzymes could be extracted from thermophilic microorganisms (Kademi et al., 2000a; Markossian et al., 2000). A thermostable esterase with an optimum temperature of 60 and $70-75^{\circ} \mathrm{C}$ was also reported for Bacillus circulans (Kademi et al., 2000b) and Bacillus thermoleovorans ID-1 (Lee et al., 1999), respectively.

The thermal stability profile of A. gonensis A4 esterase in the form of residual activity was presented in Fig. 4. The enzyme was stimulated by keeping at $30-50^{\circ} \mathrm{C}$ and almost retained its original activity at 60 and $70^{\circ} \mathrm{C}$ for $1 \mathrm{~h}$ incubation period. However, enzyme activity was fully lost at $80^{\circ} \mathrm{C}$ for the same incubation period. From both thermal activity and thermal stability profiles, it can be speculated that crude enzyme exctract prepared from $A$. gonensis A4 can be used with any temperature from 60 to $70^{\circ} \mathrm{C}$ in a biotechnological applications. These characteristics are superior to those of other notable esterases or lipases from Bacillus thermoleovorans ID-1 lipase (Lee et al., 1999) and Bacillus sp. esterase (Burcu
Table 1. Effect of some metal ions on Anoxybacillus gonensis A4 esterase activity. The esterase activity in the presence of a metal ion was compared with the control including no metal ion whose activity was taken as $100 \%$

\begin{tabular}{cc}
\hline Metal Ion $(1 \mathrm{mM})$ & Relative Activity (\%) \\
\hline $\mathrm{Cu}^{2+}$ & $69 \pm 3$ \\
$\mathrm{Ni}^{2+}$ & $80 \pm 3$ \\
$\mathrm{Ca}^{2+}$ & $86 \pm 4$ \\
$\mathrm{Mn}^{2+}$ & $96 \pm 4$ \\
$\mathrm{Hg}^{2+}$ & $47 \pm 2$ \\
$\mathrm{Zn}^{2+}$ & $59 \pm 4$ \\
$\mathrm{Co}^{2+}$ & $65 \pm 5$ \\
$\mathrm{Cd}^{2+}$ & $86 \pm 5$ \\
$\mathrm{Cr}^{3+}$ & $53 \pm 3$ \\
$\mathrm{~K}^{+}$ & $115 \pm 5$ \\
$\mathrm{Na}^{+}$ & $101 \pm 5$ \\
\hline
\end{tabular}

et al., 2006). The thermostable esterases from soil thermophilic bacterial strains were also reported to be stable in the ratio of $98 \%$ at the end of $1 \mathrm{~h}$ incubation period at $70^{\circ} \mathrm{C}$ when compared with its original activity (Kademi et al., 1999).

Substrate saturation curves for PNPB indicated that the $A$. gonensis A4 esterase follows simple Michaelis-Menten kinetics. The substrate saturation curve was obtained by interpolating the substrate concentrations against activity values. The reaction velocity increased up to approximately $360 \mu \mathrm{M}$ PNPB and then reached a constant value. Michaelis-Menten constants $\left(K_{\mathrm{m}}\right)$ and maximum reaction velocities $\left(V_{\max }\right)$ were determined as $800 \mathrm{U} / \mathrm{L}$ and $176.5 \mu \mathrm{M}$, respectively, from a Lineweaver-Burk plot (Fig. 5). Similar $K_{m}$ value $(0.18 \mathrm{mM})$ was calculated for the carboxyl esterase Rv3487c from Mycobacterium tuberculosis against PNPB and $V_{\max }$ was found to be $300.5 \mathrm{ML}^{-1} \mathrm{~s}^{-1}$ (Zhang et al., 2005).

It is known that metal ions have an important role to maintain the enzyme in active and stable structure by binding to amino acid residues with negative charge in specific sites (Çolak et al., 2005). The behaviour of A. gonensis A4 for some metal ions was examined by using chloride salts of each metals at a concentration of $1 \mathrm{mM}$ (Table 1). In the presence of $\mathrm{K}^{+}$, the enhancement of esterase activity up to $115 \pm 5 \%$ shows that this metal ion stimulates $A$. gonensis A4 esterase

Table 2. Effect of some reagents on Anoxybacillus gonensis A4 esterase activity. The esterase activity in the presence of a reagent was compared with the control which contained no reagent other than the compounds required for esterase assay. The control activity was taken as $100 \%$

\begin{tabular}{|c|c|c|c|c|c|}
\hline \multirow{2}{*}{$\begin{array}{l}\text { Concentration } \\
(\mu \mathrm{M})\end{array}$} & \multicolumn{2}{|c|}{ Relative activity (\%) } & \multirow{2}{*}{$\begin{array}{l}\text { Concentration } \\
(\mathrm{mM})\end{array}$} & \multicolumn{2}{|c|}{ Relative activity (\%) } \\
\hline & PMSF & DTT & & $2-\mathrm{ME}^{\mathrm{a}}$ & Na-EDTA \\
\hline 50 & $94 \pm 5$ & $107 \pm 5$ & 2 & $127 \pm 5$ & $79 \pm 4$ \\
\hline 100 & $90 \pm 4$ & $110 \pm 5$ & 2.5 & $130 \pm 5$ & $56 \pm 3$ \\
\hline 250 & $85 \pm 4$ & $118 \pm 4$ & 5 & $153 \pm 5$ & $32 \pm 3$ \\
\hline
\end{tabular}

a2-Mercaptoethanol 
activity. In addition, all tested divalent and trivalent metal ions inhibited enzyme activity in different ratio but not completely. The inhibiton of esterase activity in the presence of EDTA (ethylenediamine tetraacetic acid) can be attributed to its metal chelating effect (Table 2). However, Dithiotreitol (DTT) and mercaptoethanol as reducing agent of disulfide bridges were also stimulated enzyme activity. It can be concluded from this result that $-\mathrm{SH}$ groups were essential for PNPB hydrolysis. The inhibition of enzyme activity with $\mathrm{Hg}^{2+}$ was also supported this result (Kademi et al., 2000a). The little inhibition of esterase activity by PMSF may be attributed to the presence of serine residues responsible for the hydrolytic reaction in the active site since this inhibitor is known to interact selectively and irreversibly with the serine hydroxyl groups.

In conclusion, a thermophilic bacterium A. gonensis A4 isolated from hot springs in Turkey, secretes an extracellular hydrolase responsible for the degradation of some $p$-nitrophenyl esters. This extracellular crude preparation was investigated in terms of substrate specificity, $\mathrm{pH}$ and temperature optima, stability and kinetic parameters. It was found that $A$. gonensis A4 produced a good thermostable extracellular esterase and enzyme was highly stable at near neutral $\mathrm{pH}$ values. The stimulation of enzyme activity in the presence of DTT and Mercaptoethanol and inhibitor effect of $\mathrm{Hg}^{2+}$ shows that - $\mathrm{SH}$ groups in specific sites were required.

Acknowledgments This work was supported by a research grant to AC from the Research Fund of Karadeniz Technical University, Turkey (Pr. Nr. 2002.111.002.3).

\section{References}

Azzolina, O., Vercesi, D., Collina, S. and Ghislandi, V. (1995) Chiral resolution of methyl 2-aryloxypropionates by biocatalytic stereospecific hydrolysis. Farmaco. 50, 221-226.

Baumann, M., Hauer, B. and Bornscheuer, U. T. (2000) Rapid screening of hydrolases for the enantioselective conversion of 'difficult-to-resolve substrates'. Tetrahedron-Asymmetr. 11, 4781-4790.

Belduz, A. O., Dulger, S. and Demirbag, Z. (2003) Anoxybacillus gonensis sp. nov., a moderately thermophilic, xylose-utilizing, endospore-forming bacterium. Int. J. Syst. Evol. Micr. 53, 13151320.

Bornscheuer, U. T. (2002) Microbial carboxyl esterases: classification, properties and application in biocatalysis. FEMS Microbiol. Rev. 26, 73-81.

Burcu, Z., Ateplier, B. and Metin, K. (2006) Production and partial characterization of a novel thermostable esterase from a thermophilic Bacillus sp. Enzyme Microb. Tech. 38, 628-635.

Choi, Y. J. and Lee, B. H. (2001) Culture conditions for the production of esterase from Lactobacillus casei CL96. Bioproc. Biosyst. Eng. 24, 59-63.

Colak, A. and Güner, S. (2004) Polyhydroxyalkanoate degrading hydrolase-like activities by Pseudomonas sp. isolated from soil. Int. Biodeter. Biodegr. 53, 103-109.
Çolak, A., bipik, D., Saglam, N., Güner, S., Çanakçi, S. and Beldüz, A. O. (2005) Characterization of a thermoalkalophilic esterase from a novel thermophilic bacterium, Anoxybacillus gonensis G2. Bioresour. Technol. 96, 625-631.

Eggert, T., Pouderoyen, G. V., Pencreac'h, G., Douchet, I., Verger, R., Dijsktra, B. W. and Jeager, K. (2002) Biochemical properties and three dimensional structures of two extracellular lipolitic enzymes from Bacillus subtilis. Colloid Surface B. 26, $37-46$.

Fojan, P., Jonson, P. H., Petersen, M. T. N. and Petersen, S. B. (2000) What distinguishes an esterase from a lipase: a novel structural approach. Biochimie. 82, 1033-1041.

Gowland, R. K., Kernick, M. and Sundaram, T. K. (1987) Thermophilic bacterial isolates producing lipase. FEMS Microbiol. Lett. 48, 339-343.

Hotta, Y., Ezaki, S., Atomi, H. and Imanaka, T. (2002) Extremely stable and versatile carboxylesterase from a hyperthermophilic archaeon. Appl. Environ. Microb. 68, 3925-3931.

Jung, Y., Lee, J., Sung, C., Oh, T. K. and Kim, H. K. (2003) Nonionic detergent-induced activation of an esterase from Bacillus megaterium 20-1. J. Mol. Catal. B-Enzym. 26, 223229.

Kademi, A., Ait- Abdelkader, N., Fakhreddine, L. and Baratti, J. C. (1999) A thermostable esterase activity from newly isolated moderate thermophilic bacterial strains. Enzyme Microb. Tech. 24, 332-338.

Kademi, A., Ait- Abdelkader, N., Fakhreddine, L. and Baratti, J. C. (2000a) Purification and characterization of a thermostable esterase from the moderate thermophilic bacterium Bacillus circulans. Appl. Microbiol. Biot. 54, 173-179.

Kademi, A., Ait- Abdelkader, N., Fakhreddine, L. and Baratti, J. C. (2000b) Characterization of a thermostable esterase from the moderate thermophilic bacterium Bacillus circulans. J. Mol. Catal. B-Enzym. 54, 173-179.

Kawamoto, T., Sonomoto, K. and Tanaka, A. (1987) Esterification in organic solvents: selection of hydrolases and effects of reaction conditions. Biocatalysis. 1, 137-145.

Kierstan, M. P. J. and Coughlan, M. P. (1985) Immobilization of cells and enzymes by gel entrapment; In Immobilized Cells and Enzymes: A Practical Approach, Woodward, J. (ed.), pp. 39-48, Oxford, UK.

Lee, D., Koh, Y., Kim, K., Kim, B., Choi, H., Kim, D., Suhartono, M. T. and Pyun, Y. (1999) Isolation and characterization of a thermophilic lipase from Bacillus thermoleovorans ID-1. FEMS Microbiol. Lett. 179, 393-400.

Lima, V. M. G., Krieger, N., Sarquis, M. I. M., Mitchell, D. A., Ramos, L. P. and Fontana, J. D. (2003) Effect of nitrogen and carbon sources on lipase production by Penicillium aurantiogriseum. Food Technol. Biotech. 41, 105-110.

Lineweaver, H. and Burk, D. (1934) The determination of enzyme dissociation constant. J. Am. Chem. Soc. 56, 658-661.

Lopes, M. F. S., Leitao, A. L., Regalla, M., Marques, J. J. F., Carrondo, M. J. T. and Crespo, M. T. B. (2002) Characterization of a highly thermostable extracellular lipase from Lactobacillus plantarum. Int. J. Food Microbiol. 76, 107115.

Lowry, O. H., Rosebrough, N. J., Farr, A. L. and Randall, R. J. (1951) Protein mesurement with the folin phenol reagent. $J$. Biol. Chem. 193, 265-275.

Markossian, S., Becker, P., Mark, H. and Antranikian, G. (2000) 
Isolation and characterization of lipid-degrading Bacillus thermoleovorans IHI-91 from an ocelandic hot spring. Extremophiles. 4, 365-371.

Molinari, F., Brenna, O., Valenti, M. and Aragozzini, F. (1996) Isolation of a novel carboxylesterase from Bacillus coagulans with high enantioselectivity toward racemic esters of 1,2-Oisopropylideneglycerol. Enzyme Microb. Tech. 19, 551-556.

Musidlowska-Persson, A. and Bornscheuer, U. T. (2003) Recombinant porcine intestinal carboxylesterase: cloning from the pig liver esterase gene by site-directed mutagenesis, functional expression and characterization. Protein Eng. 16, 1139-1145.

Nawani, N. and Kaur, J. (2000) Purification, characterization and thermostability of a lipase from a thermophilic Bacillus sp. J33. Mol. Cell. Biochem. 206, 91-96.

Ollis, D. L., Shea, E., Cygler, M. B., Dijkstra, B. and Frolow, F. (1992) The á/â hydrolase fold. Protein. Eng. 5, 197-211.

Owusu, R. K. and Cowan, D. A. (1989) Correlation between microbial protein thermostability and resistance to denaturation in aqueus: organic solvent two-phase systems. Enzyme Microb. Tech. 11, 568-574.

Özen, A., Colak, A., Dincer, B. and Güner, S. (2004) A diphenolase from persimmon fruits (Diospyros kaki L., Ebenaceae). Food Chem. 85, 431-437.

Quax, W. J. and Broekhuizen, C. P. (1994) Development of a new Bacillus carboxyl esterase for use in the resolution of chiral drugs. Appl. Microbiol. Biot. 41, 425-431.

Suoniemi, A. and Tynkkynen, S. (2002) Cloning and characterization of an esterase from Propionibacteriom feudenreichii ssp. Shermanii. Lait. 82, 81-89.

Tan, T., Zhang, M., Xu, J. and Zhang, J. (2004) Optimization of culture conditions and properties of lipase from Penicillium camembertii Thom PG-3. Process Biochem. 39, 1495-1502.

Teo, J. W. P., Zhang, L. and Poh, C. L. (2003) Cloning and characterization of a novel lipase from Vibrio harveyi strain AP6. Gene. 312, 181-188.

Yildirim, M., Col, M., Colak, A., Güner, S., Dülger, S. and Beldüz, A. O. (2005) Diphenolases from Anoxybacillus kestanbolensis strains $\mathrm{K} 1$ and $\mathrm{K} 4{ }^{\mathrm{T}}$. World J. Microb. Biot. 21, 501-507.

Zhang, M., Wang, J., Li, Z., Xie, J., Yang, Y., Zhong, Y. and Wang, H. (2005) Expression and characterization of the carboxyl esterase Rv3487c from Mycobacterium tuberculosis. Protein Expres. Purif. 42, 59-66. 